\title{
Relationship between genetic polymorphisms MTHFR (C677T, A1298C), MTR (A2756G) and MTRR (A66G) genes and multiple sclerosis: a case-control study
}

\author{
Suat Cakina ${ }^{1}$, Ozgul Ocak², Adile Ozkan², Selma Yucel ${ }^{2}$, Handan Isın Ozısık Karaman² \\ ${ }^{1}$ Health Service Vocational College, Canakkale Onsekiz Mart University, Çanakkale, ${ }^{2}$ Department of Neurology, Faculty of Medicine, \\ Canakkale Onsekiz Mart University, Çanakkale, Turkey
}

\begin{abstract}
Recent studies have reported elevated plasma homocysteine and reduced folate and vitamin B levels in patients with multiple sclerosis (MS). In this study, we aimed to investigate the association between MS and the following four DNA polymorphisms: MTR A[2756]G, MTHFR C[677]T, MTHFR A[1298]C and MTRR A[66]G. The DNA polymorphisms were genotyped in 80 patients with confirmed MS and 80 healthy control age- and gender-matched subjects using PCR-RFLP approach. Our results show that the frequency of the T/T genotype homozygotes for the MTHFR C[677]T polymorphism was significantly higher in patients than in controls ( $p=0.04, O R: 3.16,95 \% \mathrm{Cl}: 1.23-8.17)$. In turn, the A/A genotype of the MTHFR A[1298]C polymorphism was more frequent in controls than in patients (41.3\% vs. $32.5 \%, p=0.04)$. There were no differences in distribution of genotypes for the MTR A[66]G and MTR A[2756]C polymorphisms between patients with MS and controls ( $p>0.05$ ). Our findings suggested that the MTHFR C[677]T and MTHFR A[1298]C gene polymorphisms might be associated with MS as genetic factors influencing the risk of the disease.
\end{abstract}

Key words: DNA polymorphism, MTHFR gene, MTR gene, MTRR gene, multiple sclerosis.

\section{Introduction}

Multiple sclerosis (MS) is a chronic inflammatory disease of the central nervous system (CNS). The aetiology of MS remains still unknown. Several studies suggest that both genetic and environmental factors contribute to the etiology of this disease. Recently, it has been reported that serum homocysteine and vitamin B12 levels may be changed in MS patients. It was reported that vitamin B12 levels were low and homocysteine levels were high in MS patients $[2,5,12,14,16,19]$.

Methylenetetrahydrofolate reductase (MTHFR), methionine synthase (MTR) and methionine synthase reductase (MTRR) are essential enzymes in folate and Hcy metabolism, also in methylation reactions which provide a methyl group for conversion of homocysteine into methionine. MTHFR converts 5,10-methylenetetrahydrofolate, in a reaction catalysed by MTR. MTRR is a coenzyme that catalyses the remethylation of homocysteine (Hcy) to methionine via a cobalamin and folate-dependent reaction $[6-8,10,18]$.

In the MTHFR gene, C[677]T (rs1801133) and A[1298]C (rs1801131) polymorphisms affecting the activity of the methionine synthase reductase have been identified. They have been associated with decreased enzyme activity and increased levels of

Communicating author

Dr Suat Cakina, Health Service Vocational College, Canakkale Onsekiz Mart University, Çanakkale, Turkey,

e-mail: suatcakina@comu.edu.tr 
plasma homocysteine [3,4,8-10]. The MTRR A[66]G (rs1801394) polymorphism alters isoleucine into a methionine residue in the protein chain. It has been suggested that the $\mathrm{G} / \mathrm{G}$ genotype of MTRR A[66]G polymorphism is negatively correlated with plasma homocysteine levels $[4,8,13]$. In the MTR gene, an adenine to guanine transition at position 2756 (A > G, rs1805087) results in substitution of aspartic acid with glycine in codon 919 of the protein $[10,11]$. Some studies reported that this MTR gene polymorphism had an effect in increasing Hcy concentration in carriers of the wild-type MTR*A[2756] allele. The variability of genes linked to folate and Hcy metabolism influence homocysteine and vitamin B12 levels, therefore they may play an important role in susceptibility to MS as a risk factor $[4,8,10,11,19]$.

In the present study, we have investigated the association between four SNPS within MTHFR, MTR and MTRR genes and susceptibility to MS.

\section{Material and methods \\ Patients and samples}

The case-control study consisted of 80 MS patients (24 men and 56 women; $43.18 \pm 11.27$ years old) and 80 healthy controls ( 27 men and 53 women; $38.06 \pm$ 9.31 years old), which had been matched for age and gender. The MS population was obtained from patients hospitalized in the neurology department at the University Hospital of Canakkale Onsekiz Mart, Turkey, and the diagnosis was made by a neurologist according to the revised McDonald criteria [15]. Approval for the study was obtained from the Ethics Committee of Canakkale Onsekiz Mart University Faculty of Medicine. Genomic DNA was isolated from peripheral blood samples by using a DNA extraction kit (Bionner,
Korea) according to the manufacturer's instructions. Genotyping of all DNA polymorphisms was performed with the use of PCR-RFLP approach. PCR conditions including sequences of primers were based on the methodology from previous studies [10,11,13]. Details of PCR conditions are presented in Table I. The restriction fragments obtained during digestion of PCR products by different restriction enzymes were separated by electrophoresis in 2-3\% agarose gels with ethidium bromide and visualized in UV light using transilluminator.

\section{Statistical analysis}

Data analysis was performed using the computer software Statistical Package for Social Sciences (SPSS) for Windows (version 19.0 for Windows; IBM Inc. Armonk, NY, USA). Kolmogorov-Smirnov test was used to assess the normality of data distribution. Genotype frequencies were tested on the HardyWeinberg equilibrium with the $\chi^{2}$ test. Statistical difference was considered significant for $P$ values less than 0.05. The association between these genotypes and the risk of MS was estimated by computing the odds ratios (ORs) and their 95\% confidence intervals (Cls) from binary logistic regression analysis.

\section{Results}

Demographic and clinical characteristics of MS patients and healthy controls are presented in Table II. The average age of the patients was $43.28 \pm 11.2$ years and was fully matched with control individuals (38.06 \pm 9.3 years). No significant difference was found between cases and controls with regard to sex since $70.0 \%$ and $68.3 \%$ of the patients and controls were females, respectively. Patients have

Table I. PCR-RFLP conditions used for the analysis of the selected polymorphisms in the MTHFR, MTR and MTRR genes

\begin{tabular}{|c|c|c|c|c|c|}
\hline $\begin{array}{c}\text { Gene } \\
\text { polymorphism }\end{array}$ & Primers & $\mathrm{T}_{\mathrm{m}}\left({ }^{\circ} \mathrm{C}\right)$ & $\begin{array}{l}\text { PCR product } \\
\text { (bp) }\end{array}$ & $\begin{array}{l}\text { Restriction } \\
\text { enzyme }\end{array}$ & Alleles (bp) \\
\hline $\begin{array}{l}\text { MTHFR C677T } \\
(\text { rs1801133) }\end{array}$ & $\begin{array}{l}\text { F: 5'-TGAAGGAGAAGGTGTCTGCGGGA-3' } \\
\text { R: 5'-AGGACGGTGCGGTGAGAGTG-3' }\end{array}$ & $58^{\circ} \mathrm{C}$ & 198 & Hinfl & $\begin{array}{l}\text { C: } 198 \\
\text { T: } 23,175\end{array}$ \\
\hline $\begin{array}{l}\text { MTHFR A1298C } \\
\text { (rs1801131) }\end{array}$ & $\begin{array}{c}\text { F: 5'-CTTTGGGGAGCTGAAGGACTACTAC-3' } \\
\text { R: 5'-CACTTTGTGACCATTCCGGTTTG-3' }\end{array}$ & $52^{\circ} \mathrm{C}$ & 163 & Mboll & $\begin{array}{l}\text { A: } 100 \\
\text { C: } 63\end{array}$ \\
\hline $\begin{array}{l}\text { MTR (A2756G, } \\
\text { rs1805087) }\end{array}$ & $\begin{array}{l}\text { F: 5'-GAACTAGAAGACAGAAATTCTCTA-3' } \\
\text { R: 5'-ATGGAAGAATATCAAGATATTAGA-3' }\end{array}$ & $53^{\circ} \mathrm{C}$ & 189 & Haelll & $\begin{array}{c}\text { A: } 189 \\
\text { G: } 30,159\end{array}$ \\
\hline $\begin{array}{l}\text { MTRR A66G } \\
(\text { rs1801394) }\end{array}$ & $\begin{array}{l}\text { F: 5'-GCAAAGGCCATCGCAGAAGACAT-3' } \\
\text { R: 5'-TGAAGATCTGCAGAAAATCCATGTA-3' }\end{array}$ & $60^{\circ} \mathrm{C}$ & 118 & Nspl & $\begin{array}{c}\text { A: } 118 \\
G: 24,94\end{array}$ \\
\hline
\end{tabular}


been classified into three subgroups as follows: 1) relapsing-remitting MS (RRMS), 2) secondary progressive MS (SPMS), and 3) primary progressive MS (PPMS). The whole group of 80 patients consisted of 55 RRMS, 15 SPMS, and 10 PPMS patients.

The observed and expected frequencies of all the DNA polymorphisms in both groups were in HardyWeinberg equilibrium.

The frequencies of all genotypes (CC, CT, and TT) for the MTHFR C[677]T polymorphism in patients were statistically different from those in controls

Table II. Demographic and clinical details of MS patients and healthy controls

\begin{tabular}{|lcc|}
\hline & Cases $(n=80, \%)$ & Controls $(n=80, \%)$ \\
\hline Age $($ mean \pm SD) & $43.28 \pm 11.2$ & $38.06 \pm 9.3$ \\
\hline Male & $24(30)$ & $27(33.8)$ \\
\hline Female & $56(70)$ & $53(66.2)$ \\
\hline RRMS & $55(68.8)$ & \\
\hline PPMS & $15(18.8)$ & \\
\hline SPMS & $10(12.4)$ & \\
\hline
\end{tabular}

SD - standard deviation, PPMS - primary progressive MS, SPMS - secondary progressive MS, RRMS - relapsing-remitting MS
( $40.0 \%, 37.5 \%$ and $22.5 \%$ vs. $56.3 \%, 33.8 \%$ and $9.9 \%$, respectively). The frequency of the $T / T$ genotype for the MTHFR C[677]T polymorphism was significantly higher in patients than in controls $(p=0.04$, OR: 3.16, 95\% Cl: 1.23-8.17). Differences between controls and MS patients were observed also for MTHFR ${ }^{*} \mathrm{C}[677]$ or MTHFR ${ }^{*}$ [677] allele frequencies $(p=0.01)$.

For the MTHRF A[1298]C polymorphism, the $\mathrm{A} / \mathrm{A}$ genotype was more frequent in controls than in patients $(41.3 \%$ vs. $32.5 \%, p=0.04)$.

For MTR A[2756]G and MTRR A[66]G polymorphisms, there was no difference in allele frequencies between healthy subjects and the MS group $(p>0.05)$ (Table III).

After stratification of a cohort of MS patients into three subgroups of subjects with a different disease course (RRMS, SPMS, PPMS), no statistically significant difference $(p>0.05)$ in genotype frequencies for all four DNA polymorphisms analysed was observed (Table IV).

\section{Discussion}

Many studies showed that genome variability, mainly SNPs (single nucleotide polymorphisms),

Table III. Distribution of the MTHFR, MTR and MTRR genes of genotypes and alleles in cases and controls

\begin{tabular}{|c|c|c|c|c|c|c|c|}
\hline & \multirow[t]{2}{*}{ Genotypes } & \multicolumn{2}{|c|}{ Cases } & \multicolumn{2}{|c|}{ Controls } & \multirow[t]{2}{*}{$p$ value } & \multirow[t]{2}{*}{ OR $(95 \% \mathrm{Cl})$} \\
\hline & & $n=80$ & $n(\%)$ & $n=80$ & $n(\%)$ & & \\
\hline \multirow[t]{5}{*}{ C677T } & CC (wild type) & 32 & 40.0 & 45 & 56.3 & 0.04 & ref \\
\hline & CT & 30 & 37.5 & 27 & 33.8 & & $1.56(0.78-3.11)$ \\
\hline & TT & 18 & 22.5 & 8 & 9.9 & & $3.16(1.23-8.17)$ \\
\hline & $\mathrm{C}$ & 94 & 58.8 & 117 & 73.1 & 0.01 & ref \\
\hline & $T$ & 66 & 41.2 & 43 & 26.9 & & $1.91(1.19-3.06)$ \\
\hline \multirow[t]{5}{*}{ A1298C } & AA (wild type) & 26 & 32.5 & 33 & 41.3 & 0.04 & ref \\
\hline & $A C$ & 45 & 56.2 & 30 & 37.5 & & $1.90(0.95-3.80)$ \\
\hline & $\mathrm{CC}$ & 9 & 11.3 & 17 & 21.2 & & $0.67(0.26-1.75)$ \\
\hline & A & 97 & 60.6 & 96 & 60.0 & 0.97 & ref \\
\hline & C & 63 & 39.4 & 64 & 40.0 & & $0.97(0.62-1.53)$ \\
\hline \multirow[t]{5}{*}{ A2756G } & AA (wild type) & 58 & 72.5 & 61 & 76.3 & 0.78 & ref \\
\hline & $\mathrm{AG}$ & 16 & 20.0 & 15 & 18.8 & & $1.12(0.51-2.17)$ \\
\hline & GG & 6 & 7.5 & 4 & 4.9 & & $1.58(0.42-5.88)$ \\
\hline & A & 132 & 82.5 & 137 & 85.6 & 0.55 & ref \\
\hline & $\mathrm{G}$ & 28 & 17.5 & 23 & 14.4 & & $1.26(0.69-2.31)$ \\
\hline \multirow[t]{5}{*}{$A 66 G$} & AA (wild type) & 11 & 13.8 & 18 & 22.5 & 0.31 & ref \\
\hline & $A G$ & 65 & 81.3 & 57 & 71.3 & & $1.87(0.81-4.28)$ \\
\hline & GG & 4 & 4.9 & 5 & 6.2 & & $1.31(0.29-5.95)$ \\
\hline & A & 87 & 54.4 & 93 & 58.1 & 0.50 & ref \\
\hline & $G$ & 73 & 45.6 & 67 & 41.9 & & $1.17(0.75-1.81)$ \\
\hline
\end{tabular}


Table IV. Distribution of the MTHFR, MTR and MTRR genes of genotypes in the disease course of MS patients

\begin{tabular}{|c|c|c|c|c|c|c|c|c|}
\hline & \multirow[t]{2}{*}{ Genotypes } & \multicolumn{2}{|c|}{ PPMS } & \multicolumn{2}{|c|}{ SPMS } & \multicolumn{2}{|c|}{ RRMS } & \multirow[t]{2}{*}{$p$ value } \\
\hline & & $n$ & $n(\%)$ & $n$ & $n(\%)$ & $n$ & $n(\%)$ & \\
\hline \multirow[t]{3}{*}{ С677Т } & CC (wild type) & 1 & 3.1 & 6 & 78.1 & 25 & 18.8 & 0.08 \\
\hline & $\mathrm{CT}$ & 6 & 20.0 & 21 & 70.0 & 3 & 10.0 & \\
\hline & $\mathrm{TT}$ & 3 & 16.7 & 9 & 50.0 & 6 & 33.3 & \\
\hline \multirow[t]{3}{*}{ A1298C } & AA (wild type) & 0 & 0.0 & 1 & 100.0 & 0 & 0.0 & 0.43 \\
\hline & $A C$ & 8 & 19.0 & 27 & 100.0 & 7 & 16.7 & \\
\hline & $\mathrm{CC}$ & 2 & 5.4 & 27 & 73.0 & 8 & 21.6 & \\
\hline \multirow[t]{3}{*}{ A2756G } & AA (wild type) & 7 & 12.1 & 38 & 65.5 & 13 & 22.4 & 0.68 \\
\hline & $A G$ & 2 & 12.5 & 13 & 81.3 & 1 & 6.3 & \\
\hline & GG & 1 & 16.7 & 4 & 66.6 & 1 & 16.7 & \\
\hline \multirow[t]{3}{*}{ A66G } & AA (wild type) & 1 & 9.1 & 10 & 90.9 & 0 & 0.0 & 0.40 \\
\hline & $A G$ & 9 & 13.8 & 42 & 64.4 & 14 & 21.5 & \\
\hline & GG & 0 & 0.0 & 3 & 75.0 & 1 & 25.0 & \\
\hline
\end{tabular}

PPMS - primary progressive MS, SPMS - secondary progressive MS, RRMS - relapsing-remitting MS

may have an effect on the risk of MS but the results are still not conclusive. Individual differences in the levels of homocysteine, vitamin B, folic acid due to genetic variations can be considered as a risk of MS. One carbon metabolism pathway (OCMP) consists of homocysteine (Hcy), folic acid (FA) and vitamin B (Vit B). Many reports showed that high levels of Hcy are toxic to neural cells. Thus, Hcy contributes to the pathogenesis of many neurodegenerative disorders such as MS, Parkinson's or Alzheimer's diseases. Patients' levels of Hcy can be determined by the MTHFR gene polymorphisms. There are conflicting data from published reports concerning the association between MTHFR C[677]T, MTHFR A[1298]C, MTR $(A[2756] G)$ and MTRR (A[66]G) gene polymorphisms and the risk of MS. Studies performed in other populations of MS patients have shown that carriers of the $T / T$ and $C / C$ genotypes of the MTHFR C[677]T polymorphism have reduced activity of methionine synthase reductase.

Çevik et al. found also that the MTHFR *T[677] allele was associated with MS susceptibility [1].

Fekih Mrissa et al. reported statistically significant differences in the distribution of the MTHFR A[1298]C polymorphism between controls and MS patients. The C/C genotype was associated with almost 4 times increased risk of MS [3].

Naghibalhossaini et al. reported that the $\mathrm{C} / \mathrm{T}$ genotype of MTHFR C[677]T showed a higher risk of
MS incidence for both cases with the recessive (TT vs. CT + CC) and codominant (CT vs. CC) pattern of inheritance (for T/T vs. CC: $O R=6.23,95 \% \mathrm{Cl}=3.08$ 12.59 and $C / T$ vs. $C C: O R=2.9,95 \% \mathrm{Cl}=1.88-4.49$, respectively) in comparison with controls. They also found a higher risk of MS associated with the $A / C$ genotype of the MTHFR A[1298]C polymorphism [13].

A role of MTRR A[66]G and MTHFR A[1298]C polymorphisms in MS aetiology was investigated in an Australian case-control population study but no significant difference in the distribution of allele frequencies was observed between cases and controls [17]. In the UK Caucasian population, a similar study showed that the frequency of genotypes for MTHFR A[1298]C was different (but without statistical significance) in MS patients compared to controls [6,19].

In our study, we observed that the frequency of the T/T genotype for the MTHFR C[677]T polymorphism was significantly higher in patients than in controls ( $p=0.04$, OR: $3.16,95 \% \mathrm{Cl}: 1.23-8.17$ ). Though for the MTHFR A[1298]C polymorphism, the $A / A$ genotype was more frequent in controls than in patients $(41.3 \%$ vs. $32.5 \%, p=0.04)$. Similarly to previous studies, we found a possible link between an increased risk of MS and the MTHFR C[677]T polymorphism and a decreased risk (protective effects) of MS and the MTHFR A[1298]C polymorphism.

Any inconsistences of our findings with observations of other authors could be explained by the 
differences in a study design, sample size, method of genotyping and other environmental factors. In the future, both meta-analysis and studies with larger samples should be conducted to obtain more conclusive data. A correlation between the DNA polymorphisms genotyped in our work and the activity of enzymes encoded by MTHFR, MTR and MTRR genes requires also additional more in-depth evaluation.

\section{Acknowledgments}

This work was supported by the Scientific Research Projects Coordination Unit of Çanakkale Onsekiz Mart University. Project Number: TSA-972.

We thank the staff of the Neurology Unit of Çanakkale Onsekiz Mart University Hospital for collecting blood samples from patients with MS.

\section{Disclosure}

The authors report no conflict of interest.

\section{References}

1. Cevik B, Yigit S, Karakus N, Aksoy D, Kurt S, Ates O. Association of methylenetetrahydrofolate reductase gene C677T polymorphism with multiple sclerosis in Turkish patients. J Investig Med 2014; 62: 980-984.

2. Dyment DA, Ebers GC, Sadovnick AD. Genetics of multiple sclerosis. Lancet Neurol 2004; 3: 104-110.

3. Fekih Mrissa N, Mrad M, Klai S, Zaouali J, Sayeh A, Mazigh C, Nsiri B, Machgoul S, Gritli N, Mrissa R. Association of methylenetetrahydrofolate reductase $\mathrm{A} 1298 \mathrm{C}$ polymorphism but not of C677T with multiple sclerosis in Tunisian patients. Clin Neurol Neurosurg 2013; 115: 1657-1660.

4. Fong CS, Shyu HY, Shieh JC, Fu YP, Chin TY, Wang HW, Cheng CW. Association of MTHFR, MTR, and MTRR polymorphisms with Parkinson's disease among ethnic Chinese in Taiwan. Clin Chim Acta 2011; 412: 332-338.

5. Ineichen BV, Keskitalo S, Farkas M, Bain N, Kallweit U, Weller M, Klotz L, Linnebank M. Genetic variants of homocysteine metabolism and multiple sclerosis: a case-control study. Neurosci Lett 2014; 562: 75-78

6. Karahil AEAB. The role of folate dependent genetic susceptibility in the risk of multiple sclerosis. J Neurol Neurosci 2017; 8: 189.

7. Kocer B, Engur S, Ak F, Yilmaz M. Serum vitamin B12, folate, and homocysteine levels and their association with clinical and electrophysiological parameters in multiple sclerosis. J Clin Neurosci 2009; 16: 399-403.

8. Lajin B, Alhaj Sakur A, Michati R, Alachkar A. Association between MTHFR C677T and A1298C, and MTRR A66G polymorphisms and susceptibility to schizophrenia in a Syrian study cohort. Asian J Psychiatr 2012; 5: 144-149.

9. Li M, Fu B, Dong W. Correlations between plasma homocysteine and MTHFR gene polymorphism and white matter lesions. Folia Neuropathol 2018; 56: 301-307.
10. Li WX, Dai SX, Zheng JJ, Liu JQ, Huang JF. Homocysteine metabolism gene polymorphisms (MTHFR C677T, MTHFR A1298C, MTR A2756G and MTRR A66G) jointly elevate the risk of folate deficiency. Nutrients 2015; 7: 6670-6687.

11. Li WX, LV WW, Dai SX, Pan ML, Huang JF. Joint associations of folate, homocysteine and MTHFR, MTR and MTRR gene polymorphisms with dyslipidemia in a Chinese hypertensive population: a cross-sectional study. Lipids Health Dis 2015; 14: 101.

12. Miller A, Korem M, Almog R, Galboiz Y. Vitamin B12, demyelination, remyelination and repair in multiple sclerosis. J Neurol Sci 2005; 233: 93-97.

13. Naghibalhossaini F, Ehyakonandeh $H$, Nikseresht A, Kamali E. Association between MTHFR genetic variants and multiple sclerosis in a Southern Iranian population. Int J Mol Cell Med 2015; 4: 87-93.

14. Nylander A, Hafler DA. Multiple sclerosis. J Clin Invest 2012; 122: 1180-1188.

15. Polman CH, Reingold SC, Banwell B, Clanet M, Cohen JA, Filippi M, Fujihara K, Havrdova E, Hutchinson M, Kappos L, Lublin FD, Montalban X, O'Connor P, Sandberg-Wollheim M, Thompson AJ, Waubant E, Weinshenker B, Wolinsky JS. Diagnostic criteria for multiple sclerosis: 2010 Revisions to the McDonald criteria. Ann Neurol 2011; 69: 292-302.

16. Sumelahti ML, Tienari PJ, Hakama M, Wikstrom J. Multiple sclerosis in Finland: incidence trends and differences in relapsing remitting and primary progressive disease courses. J Neurol Neurosurg Psychiatry 2003; 74: 25-28.

17. Szvetko AL, Fowdar J, Nelson J, Colson N, Tajouri L, Csurhes PA, Pender MP, Griffiths LR. No association between MTHFR A1298C and MTRR A66G polymorphisms, and MS in an Australian cohort. J Neurol Sci 2007; 252: 49-52.

18. Tajouri L, Martin V, Gasparini C, Ovcaric M, Curtain R, Lea RA, Haupt LM, Csurhes P, Pender MP, Griffiths LR. Genetic investigation of methylenetetrahydrofolate reductase (MTHFR) and catechol-O-methyl transferase (COMT) in multiple sclerosis. Brain Res Bull 2006; 69: 327-331.

19. Zhu Y, He ZY, Liu HN. Meta-analysis of the relationship between homocysteine, vitamin $B(1)(2)$, folate, and multiple sclerosis. J Clin Neurosci 2011; 18: 933-938. 